\title{
A Comparative Meta-Analysis of 5E and Traditional Approaches in Turkey
}

\author{
Özgür Anil ${ }^{1}$, Veli Batdi ${ }^{2}$ \\ ${ }^{1}$ Doctor, Kuleli Military High School, Department of Science Courses, İstanbul, Turkey \\ ${ }^{2}$ Assistant Professor Doctor, Kilis 7 Aralık University, Education Faculty, Kilis, Turkey \\ Correspondence: Veli Batdi, Assistant Professor Doctor, Kilis 7 Aralık University, Education Faculty, Kilis, Turkey
}

Received: August 14, 2015 Accepted: September 2, 2015 Online Published: September 18, 2015

doi:10.11114/jets.v3i6.1038 URL: http://dx.doi.org/10.11114/jets.v3i6.1038

\begin{abstract}
The aim of this study is to compare the 5E learning model with traditional learning methods in terms of their effect on students' academic achievement, retention and attitude scores. In this context, the meta-analytic method known as the 'analysis of analyses' was used and a review undertaken of the studies and theses $(\mathrm{N}=14)$ executed in Turkey over the period 2008-2014 on the 5E model. The goal of the review was to determine the efficacy of the 5E instructional model in terms of academic achievement, retention and attitude scores. The treatment effect method was used in the data analysis and the Comprehensive Meta-Analysis (CMA) statistical program, the MetaWin and Microsoft Excel 2010 Office programs were employed for the effect size calculation. The effect size values resulting from the analysis were interpreted according to Cohen classification (1992). When academic achievement, retention and attitude scores in the studies implementing the 5E instructional model were calculated according to the random effects model, effect size values were found to be $\mathrm{ES}_{\text {academic achievement }}=1,132, \mathrm{ES}_{\text {retention }}$ : 1,417 and $\mathrm{ES}_{\text {attitude }}=0,552$, respectively. In regard to academic achievement and retention, it can be inferred that these effect sizes of the $5 \mathrm{E}$ learning cycle were large and medium with respect to attitude, while both were positive and significant. It can therefore be said that the 5E model has a positive effect on academic achievement, retention and attitude scores.
\end{abstract}

Keywords: 5E learning cycle model, academic achievement, retention, attitude, meta-analysis

\section{Introduction}

Constructivist learning theory is based on a philosophical understanding quite different from objectivist methodology, in terms of what knowledge is and what it means to know something. The objectivist view lies at the foundation of the perspective in the belief that knowledge or meaning does not exist in the external world independent of the individual; that is, it is not passively transmitted from the outside world into the mind of the individual but, rather, it is effectively constructed by the individual in the mind (Duffy \& Jonassen, 1991; Cunningham, 2001; cited in Deryakulu, 2001). In designing teaching processes based on the constructivist theory of learning, one of the most useful forms used is the 5E instructional model developed by Bybee, a leading scientist in the Biological Science Curriculum Study (BSCS) (Bybee, 1997). This model is based on 5 different stages of learning: Engage, Explore, Explain, Elaborate and Evaluate.

In the process of meeting the goals defined in science education, it can be seen that the $5 \mathrm{E}$ teaching model is preferred by educators, due to its foundation in the constructivist theory of learning and its status as a planned methodology in science education that offers students effective learning opportunities. Research on the 5E instructional model supports the view that this methodology can result in significant gains in the process of learning science. Some of the positive behavior and skills achieved by using the $5 \mathrm{E}$ instructional model in science education have been expressed in terms of attaining increased success in teaching science with the model, helping students to retain better concepts in their minds, achieving the development of improved attitudes and behaviour toward lessons, developing reasoning skills and superior processing skills (Lawson, Abraham, \& Renner, 1989; Brooks \& Brooks, 1993; Brown, Collins \& Duguid, 1989; Boddy, Watson \& Aubusson, 2003).

Furthermore, activities prepared in line with the model can rescue students from passivity and encourage them to be research-minded, active participants (Ağgül-Yalçın \& Avinç-Akpınar, 2010). The model, in which the student plays an active role and the teacher is a guide, is focused not on the product but on the process of learning. In addition, by directing students in the process of learning by experiencing, the model associates the learning environment with the actual world outside the classroom (Dikici, Türker \& Özdemir, 2010). It is for this reason that, in the 5E model, the 
student is able to understand and interpret the topic on his/her own, thereby rendering the learning process meaningful and permanent.

Most of the research in Turkish and international literature on the 5E instructional model has engaged with students' academic achievement, their attitudes toward their lessons, conceptual changes and the adequacy of learning environments designed within the framework of the 5E model. In the instruction based on the 5E instructional model designed by Evans (2004), it has been reported that students actively participated in the classes while the units were studied, so taking on responsibilities. However, it was also stated that the teacher needed more time for classroom preparation in order to implement the $5 \mathrm{E}$ instructional model. Newby (2004) finds that the implementation of the $5 \mathrm{E}$ instructional model renders students more comfortable in the learning environment and that their achievement levels increase when experiments are included in the lessons.

Boddy, Watson \& Aubusson (2003) have developed a unit study based on the 5E model which students found to be interesting and entertaining and then exhibited improvements in the scientific processing skills as an outcome of their work with the model. Similarly, Liu, Peng, Wu and Lin (2009) found, in their research, that a student group exposed to the 5E model recorded improvements in their scientific knowledge and perceptions. At the same time, Wilder \& Shuttleworth (2004) found that, at the end of an instructional period using this model, students inquired into the knowledge they had already brought into the learning environment. That is, when they were exposed to real-life situations, the students used their observations and data to offer scientific explanations, and that, with regard to scientific concepts, they passed through an accurate interpretation process.

Another research study on the 5E model of instruction has been produced by Saunders and Stringham (1998). The results of this study reveal that the observation that students became motivated and excited about discovering knowledge with the help of experiments. Similarly, Moseley and Reinke (2002) report that, with the help of activities they have prepared based on the 5E model, students have been able to discover concepts of science and associate these concepts with situations in real life as they implemented them. Ergin (2006) has also made a comparison of students being exposed to the $5 \mathrm{E}$ model of instruction as opposed to those who have been taught by traditional methods, finding a significant positive difference in the group of students learning the material via the $5 \mathrm{E}$ model.

In the Turkish literature, Balc1 (2005) has designed an instruction based on the 5E instructional model finding, at the end of the instruction, that students registered significant learning and exhibited conceptual changes independent of content. In a parallel study by Çepni, Küçük and Bacanak (2004), materials were developed for and used in different stages of the model.

In learning settings designed in keeping with the 5E model, students are more active than the teacher; it has been concluded that, in this situation, students are able to use their critical thinking, problem-solving, discussion and teamwork skills more effectively, and that the social communication in which the students engage with their peers is at its highest levels. Again, other research conducted in this area has shown that students interact with their friends, using what they have learnt in similar situations (Arends, 2001; Windschitl, 2000), recording their observations and thoughts regarding different activities and asking appropriate questions during subsequent opportunities for inquiry (Trowbridge, Bybee \& Powell, 2000).

It may be said that the 5E instructional model not only increases the curiosity to explore, but encompasses skills and activities that satisfy students' expectations, leading them to focus on active learning and understanding. Research has shown that the $5 \mathrm{E}$ instructional model engages students in the activity at hand at every stage, so supporting them in making their own conceptualizations (Martin, 2000). As an effective tool that enhances the thoughts of the student about the nature of science and advances laboratory skills (Köseoğlu \& Tümay, 2010), the 5E instructional model stands out as a helpful and regulating model in the teacher's quest to structure the learning environment. Encouraging experience-based learning, increasing students' curiosity to explore, helping the student to construct the knowledge and independent of the content to create consistent conceptual change, the 5E instructional model is believed to contribute to the development of students' advanced level scientific processing skills.

\subsection{Purpose and Significance of the Research}

The present meta-analytical study was conducted to examine how the 5E instructional model compared with traditional teaching methods in terms of students' academic achievement and their retention and attitude scores. The 5E model is based on a constructivist approach that relies upon building new knowledge on a foundation of old knowledge. Studies carried out on this subject have been conducted for the purpose of investigating the impact of the 5E model on different school subjects and variables (Öztürk, 2008; Açışl1, Yalçın \& Turgut, 2011; Turgut \& Gürbüz, 2011; Uzunöz, 2011; Kanlı \& Yağbasan, 2008).

However, the present study encompasses an investigation into the subject by examining the relevant research (articles, 
theses) on the basis of the defined criteria set forth in the works, in an attempt to produce an article of quality in its own right. Since the paper is a meta-analytical review of the research that has already been executed, it is believed that the investigation will lead to more comprehensive and generalised conclusions. Meta-analysis is known as the "analysis of analyses" and is based upon a combination of the results of studies that have been carried out independent of each other (Glass, 1976). It is then expected that contributions made to the literature will, in this respect, offer researchers the opportunity to approach any new studies they may undertake from a new and different perspective. In this context, the present study thus seeks to answer the following questions:

1) How does the $5 E$ instructional model compare with traditional teaching methods in terms of academic achievement with respect to effect size values?

2) What is the effect value of the model in question with respect to students' retention scores?

3) What is the effect value of this model with respect to students' attitudes?

\section{Method}

This study used the meta-analytical method to calculate the effect size of the impact of the 5E instructional model on academic achievement, retention and attitudes. This method combines the results of independently conducted studies to reach a general conclusion (Glass, 1976, p.3). In this context, a review was made of the articles on the 5E instructional model printed and made accessible on the Google Scholar database of the Board of Higher Education's National Thesis Centre between the years 2008-2014. A total of 161 (118 articles and 43 theses) publications were accessed and the appropriate analysis performed. Based on the inclusion criteria for the studies collected, 14 were reviewed in the research (Academic achievement $\mathrm{N}_{\mathrm{N}: 13}$ Retention $_{\mathrm{N}: 5}$ and Attitude $_{\mathrm{N}: 8}$ ). Some of the studies were excluded from the research because they did not reflect the relevant nature of experimental research.

On the other hand, following the review of the existing literature, the studies accessed were examined in terms of their suitability according to the inclusion criteria. In this sense, consideration was given to studies that suited the following criteria: having been conducted in the period 2008-2014; containing statistical values such as sample size (n); arithmetic means $(\mathrm{X})$ and standard deviation (ss) that would lead to establishing effect size values; and the use of a pretest-posttest and control group model. In the meta-analysis, a coding system was used through which the studies were to be identified under two headings, "Study Identity" and statistical information, set forth as "Study data." The goal of the review was to determine the efficacy of the $5 \mathrm{E}$ instructional model in terms of academic achievement, retention and attitude scores.

\subsection{Data Analysis}

The statistical data of the works included in this meta-analytic study were calculated according to Hedges' $d$. This value is the foundation of the analysis that was carried out. Moreover, the effect size values for the studies analysed were subjected to a heterogeneity test using an appropriate model. To this end, heterogeneity was explored using the commonly applied Cochran's Q test, which measures chi-square distribution with (k-1) degrees of freedom. Chi-square tests are used in analysis to test the null hypothesis that all studies are conducted to evaluate the same effect (Higgins, Thompson, Deeks \& Altman, 2003). Additionally, to calculate the difference between study and control group mean values in experimental studies, expressed as $\mathrm{d}=(\mathrm{Xe}-\mathrm{Xc}) / \mathrm{SD}$ (Hunter \& Schmidt, 1990; cited in Camnalbur \& Erdoğan, 2008), the statistical analysis method of examining study effect was used.

At this stage, the Fixed Effects Model (FEM) and the Random Effects Model (REM) were used to combine the effect size values. The effect size values resulting from the analysis were interpreted according to Cohen's classification (1992, p. 99). These values were classified as $\leq 0.20$ for a small effect size, 0.50 for a moderate effect size and $\geq 0.80$ for a large effect size. In addition, all of the analysis in the study was performed with the Comprehensive Meta Analysis (CMA) statistical program and the MetaWin package program. To ensure the reliability of the study, the works to be analysed were evaluated by an expert in the field independent of the author and the results attained were recorded. Interrater reliability between the interpretations of the two encoders was examined for consistency using Miles and Huberman's (1994) intercoder reliability formula [agreement / agreement + disagreement) $x$ 100]; this was calculated as $100 \%$.

\section{Results}

The effect sizes related to the academic achievement, retention and attitude scores set forth in the studies and included in the analysis are presented in Table 1 . Studies published in the Turkish literature on implementations of the 5E instructional model have been included in the meta-analysis. Moreover, when all the studies analysed are considered, it can be seen that the number of students whose academic achievement, retention and attitude scores were calculated were 336, 149 225, respectively; with the scores of the control group being 324, 137, 211, respectively. 


\subsection{Analysis Results Regarding the Academic Achievement Scores in the Studies}

The homogeneous distribution value, mean effect sizes and confidence intervals based on statistical models of the academic achievement scores in the studies on the 5E instructional model included in the meta-analysis are given in Table 1. In the analysis of these studies according to the fixed effects model, standard error was calculated as 0.084 ; the upper limit of the confidence interval of $95 \%$ was found to be 1.121 , the lower limit 0.791 . Mean effect size was calculated as 0.956 . These values show that academic achievement scores were better than recorded with traditional teaching methods. Furthermore, the results of the Z-test yielded $\mathrm{z}=11.350$, indicating that the analysis was of statistical significance.

At the same time, the results of the homogeneity test yielded a Q-statistic of 93.709, while the chi-square ( $\chi 2)$ table indicated $95 \%$ significance and the value at 12 degrees of freedom was found to be 21.026 . Thus, the critical value of $\chi^{2}$ distribution of $\left(\chi_{(0.95)}=21.026<93.709\right)$ was seen to exceed the Q-statistic. This finding indicates that the distribution of the studies' effect sizes is heterogeneous. For this reason, it was thought that the analysis should be performed not with a fixed effects model, but according to the random effects model, so that errors stemming from the heterogeneous quality of the sample could be eliminated.

Table 1. Homogeneous distribution values, mean effect sizes and confidence intervals of the studies included in the meta-analysis that contains academic achievement, retention and attitude scores

\begin{tabular}{lcccccccccc}
\hline $\begin{array}{c}\text { Type of } \\
\text { Test }\end{array}$ & $\begin{array}{c}\text { Type of } \\
\text { Model }\end{array}$ & $\mathrm{n}$ & $\mathrm{Z}$ & $\mathrm{p}$ & $\mathrm{Q}$ & $\mathrm{df}$ & $\mathrm{N} E$ & \multirow{2}{*}{ ES } & $\begin{array}{c}\text { 95\% Confidence Interval } \\
\text { Lower Limit }\end{array}$ \\
\hline Upper Limit \\
\hline Ach. & FEM & 13 & 11.350 & 0.000 & 93.709 & 12 & 0.084 & 0.956 & 0.791 & 1.121 \\
Achiev. & REM & 13 & 4.748 & 0.449 & 11.975 & 12 & 0.238 & 1.132 & 0.665 & 1.599 \\
Retention & FEM & 5 & 8.185 & 0.000 & 41.535 & 4 & 0.130 & 1.065 & 0.810 & 1.320 \\
& REM & 5 & 3.255 & 0.311 & 4.792 & 4 & 0.435 & 1.417 & 0.564 & 2.270 \\
Attitude & FEM & 8 & 4.711 & 0.000 & 42.302 & 7 & 0.098 & 0.464 & 0.271 & 0.657 \\
& REM & 8 & 2.252 & 0.43113 & 7.018 & 7 & 0.245 & 0.552 & 0.071 & 1.032 \\
\hline
\end{tabular}

Ach. Achiev.: Academic Achievement

Based on this distribution, when the 13 studies on the $5 \mathrm{E}$ instructional model were compared according to the random effects model, it was found that standard error was 0.238 and the upper limit of the $95 \%$ confidence interval was 1.599 , while the lower limit was 0.665 , and the effect size value was ES=1.132. Statistical significance, according to the Z-test, was found to be $\mathrm{Z}=4.748$ ( $\mathrm{p}=0.449$ ). The effect size of $\mathrm{ES}=1.132$ was found to be large and significant. Accordingly, it can be said that the applications under review and their use in the teaching process have a positive effect on academic achievement.

\subsection{Analysis Results Regarding the Retention Scores in the Studies}

The general effect sizes of students' retention scores in the studies on the 5E instructional model are presented in Table 1. In the analysis of the 5E model performed according to the fixed effects model, standard error was calculated as 0.130 ; the upper limit of the confidence interval of $95 \%$ was found to be 1.320 , the lower limit 0.810 . Mean effect size was calculated as 1.065 . These results may be interpreted in favour of the $5 \mathrm{E}$ instructional model, meaning that students' retention scores when taught with 5E were better than when traditional teaching methods were used.

The homogeneity test performed yielded a Q-statistic of 41.535, with the chi-square $\left(\chi^{2}\right)$ table indicating 4 degrees of freedom at a 95\% significance level with a critical value of 9.488. Thus, it is seen that the Q-statistic (41.535) exceeds the critical value of the chi-square distribution $\left(\chi_{(0.95)}=9.488\right)$, which indicates effect size heterogeneity. From this observation, it was decided that the effect of the retention scores should be analysed according to the random effects model.

The results of the ensuing analysis led to the calculation of an effect size of $E S=1.417$. This value indicates a positive and significant effect size for the 5E model. According to the classification by Cohen (1992), this is to be considered a large effect size. It may then be said that the 5E model had a positive impact on the retention scores of students. In addition, the Z-test was used to determine statistical significance and the result was $Z=3.255$. This result may be interpreted to mean that the analysis at $\mathrm{p}=0.311$ had no statistical significance.

\subsection{Analysis Results Regarding the Attitude Scores in the Studies}

Table 1 shows the statistical values for students' attitude scores in the studies on the 5E instructional model that were included in the meta-analysis. A careful look at the table indicates that the homogeneity test yielded a Q-statistic value of 42.302 and a $\chi 2$ distribution critical value of 14.067. In view of this result, it was observed that the Q-statistic value exceeded the $\chi^{2}$ distribution critical value $\left(\mathrm{Q}=42.302>\chi_{(0.95)} 14.067\right)$. For this reason, the effect sizes of the $5 \mathrm{E}$ instructional model attitude scores were compared using the random effects model. 
In the analysis of the 5E model performed according to the random effects model, standard error was calculated as 0.245 ; the upper limit of the confidence interval of $95 \%$ was found to be 1.032 , the lower limit 0.071 . Mean effect size was calculated as 0.552 . This result may therefore be interpreted in favour of the $5 \mathrm{E}$ instructional model, meaning that students' attitude scores when taught with $5 \mathrm{E}$ were better than when traditional teaching methods were used. The effect size, according to Cohen's (1992) classification, may then be accepted as moderate. Lastly, the z-test calculation found $\mathrm{z}=2.252$, but at $\mathrm{p}=0.431$ the analysis indicated no statistical significance.

\section{Discussion}

At the conclusion of the meta-analysis, analysis of the results was supported by the relevant literature and recommendations were set forth in the light of the results. The purpose of the study was to undertake a review of the quantitative studies carried out in Turkey and published in the national and international literature on the subject of the effect of the 5E instructional model on students' academic achievement, retention and attitude scores. When the data of the studies on students' academic achievement scores in response to the use of the $5 \mathrm{E}$ instructional model were examined according to defined criteria, it was observed that analysis performed on the basis of the fixed and random effects models indicated effect sizes that favoured the $5 \mathrm{E}$ model as opposed to other teaching methods $\left(\mathrm{ES}_{\mathrm{FEM}}=0.956\right.$, $\mathrm{ES}_{\mathrm{REM}}=1.132$ ).

These values, by Cohen's (1992) classification, indicate a large, positive and significant effect size. The results may be interpreted to mean that the $5 \mathrm{E}$ instructional model has a high impact on academic achievement. At the same time, in spite of the negative effect coefficients that were seen in the studies fitting the criteria of the analysis (Uzunöz, 2011; Keskin, 2008), as well as the positive effect values of studies that did not fit the criteria but were excluded from the analysis for various reasons while yielding values that showed the use of the 5E model to increase students' achievement scores (Tuna \& Kaçar, 2013; Ayşegül Yalçın \& Bayrakçeken, 2010; Aktaş, 2013b; Hırça, Çalık \& Seven, 2011; Açışl1, Altun Yalçın \& Turgut, 2011; Turgut \& Gürbüz, 2011; Polat \& Baş, 2012; Öztürk, 2008; Kübra Güler, 2010; Sakallı, 2011; Harurluoğlu, 2011), the results proved to be consistent with the conclusions drawn by articles, papers, Master's and Doctorate theses in the national and international literature (Bilgin, Çoşkun \& Aktaş, 2012; Liu, Peng, Wu, \& Lin, 2009; Qarareh, 2012; Odom \& Kelly 2001; Hiçcan, 2008; Pabuçcu, 2008). It is for this reason that it can be said the result of the meta-analysis of students' academic achievement is markedly consistent with the existing literature.

The 5E instructional model was also examined in terms of students' retention and attitude scores in studies using both a study group and a control group where the model was compared with traditional teaching methods. The meta-analysis of studies that included retention and attitude scores revealed effect sizes of $1.065_{\text {retention, }} 0.464_{\text {attitude }}$ according to the fixed effects model and of $1.417_{\text {retention }}$ and $0.522_{\text {attitude }}$ according to the random effects model. These results may be interpreted in favour of the $5 \mathrm{E}$ instructional model, meaning that students' retention and attitude scores when taught with $5 \mathrm{E}$ were better than when traditional teaching methods were used. In addition, it may be said that students' retention and attitude scores using the random effects model showed, according to Cohen's (1992) classification, a positive and significant large and moderate effect size, respectively. This observation may be interpreted to mean that the use of the 5E model in the school environment has a positive impact on students' retention and attitude scores.

The results of the analysis of the retention scores are also consistent with the studies included in the analysis (Tuna \& Kaçar, 2013; Öztürk, 2008; Kübra Güler, 2010; Sakall1, 2011; Harurluoğlu, 2011). At the same time, it can also be observed that the use of the $5 \mathrm{E}$ model in the school environment has a positive effect in terms of students' attitude scores. The results of the analysis are consistent with other studies included in the analysis that have also exhibited positive effect coefficients (Aktaş, 2013; Hırça, Çalık \& Seven, 2011; Turgut \& Gürbüz, 2011; Uzun, 2011; Öztürk, 2008; Keskin, 2008) as well as with studies that were not included in the analysis (Sağlam, 2006). For this reason, it may be said that the meta-analysis is supported by the literature in the conclusions drawn regarding the effects of the $5 \mathrm{E}$ model on students' retention and attitude scores. However, it has been observed that, in some studies where the effect of the 5E instructional model on students' attitude toward their lessons has been examined, this method did not result in a significant difference in student's attitudes toward their classwork (Kılavuz, 2005; Özsevgeç, 2006; Ekici, 2007; Tiryaki, 2009).

To conclude, according to the results of the meta-analysis performed on instruction based on the $5 \mathrm{E}$ model, it has been observed that the $5 \mathrm{E}$ instructional model is generally effective in terms of students' academic achievement, as far as their retention and attitude scores are concerned. In the light of these findings, it may be suggested that more concentrated use of the 5E model will contribute to ensuring that students experience a more productive and effective course of education in their classes and their academic work. 


\section{References}

(The references marked with an asterisk (*) are used in meta-analysis study).

*Açışlı, S., Yalçın, S. A., \& Turgut, Ü. (2011). Effects of the 5E learning model on students' academic achievements in movement and force issues. Procedia Social and Behavioral Sciences, 15, 2459-2462. http://dx.doi.org/10.1016/j.sbspro.2011.04.128

*Ağgül, Y. F., \& Bayrakçeken, S. (2010). The Effect of 5E learning model on pre-service science teachers' achievement of acids-bases subject. International Online Journal of Educational Sciences, 2(2), 508-531.

*Aktaş, M. (2013). 5E öğrenme modeli ve iş birlikli öğrenme yönteminin biyoloji dersi tutumuna etkisi. [The Effect of the 5E Learning Model and Cooperative Learning Method on Attitudes toward Biology Lessons]. GUJGEF, 33(1), 109-128.

*Harurluoğlu, Y. (2011). Fen bilgisi öğretmen adaylarının tohum meyve-çiçek konularındaki başarılarına ve hatırlama düzeylerine ögrenme halkası modelinin etkisi [The effect of learning cycle model on the achievements and retention levels of pre-service science teachers in seed-fruit-flower topics]. Unpublished $\mathrm{PhD}$ thesis, Gazi University Educational Sciences Institute, Ankara.

*Hırça, N., Çalık, M., \& Seven, S. (2011). Effects of guide materials based on 5E model on students' conceptual change and their attitudes towards Physics: A Case for 'Work, Power and Energy' Unit. Journal of Turkish Science Education, 8(1), 153-158.

*Keskin, V. (2008). Yapılandırmacı 5 E öğrenme modelinin lise örgencilerinin basit sarkaç kavramları ögrenmelerine ve tutumlarina etkisi [Effectiveness of constructivist 5E learning cycle model on high school students' learning of simple pendulum concepts and attitudes]. Unpublished Master's Thesis], Marmara Üniversitesi, Eğitim Bilimleri Enstitüsü. İstanbul.

*Kübra, G. H. (2010). Karikatür kullanılarak yapılan öğretimin ilköğretim 6. sinı öğrencilerinin matematik dersi doğal sayllar alt öğrenme alanındaki akademik başarılarına ve matematik dersine karşı tutumlarına etkisi. Yayımlanmamış yüksek lisans tezi, Gazi Üniversitesi, Eğitim Bilimleri Enstitüsü, Ankara.

*Öztürk, Ç. (2008). Coğrafya öğretiminde 5 E modelinin bilimsel süreç becerilerine, akademik başarıya ve tutuma etkisi [Effect of the 5E model on scientific process skills, academic achievement and attitudes in learning geography]. Unpublished PhD thesis, Gazi University, Educational Sciences Institute, Ankara.

*Polat, S., \& Baş, G. (2012). 5E yapılandırmacı öğrenme modelinin sosyal bilgiler dersinde öğrencilerin erişi düzeyine etkisi. [Effect of the 5E constructivist learning model on students' academic achievement in social studies]. Çankirı Karatekin University, Journal of Social Sciences Institute, 3(2), 69-92.

*Tuna, A., \& Kaçar, A. (2013). The effect of 5E learning cycle model in teaching trigonometry on students' academic achievement and the permanence of their knowledge. International Journal on New Trends in Education and Their Implications, 4(1), 73-87.

*Turgut, Ü., \& Gürbüz, F. (2011). Effects of teaching with 5E model on students' behaviors and their conceptual changes about the subject of heat and temperature. International Online Journal of Educational Sciences, 3(2), 679-706.

*Uzunöz, A. (2011). The effects of the activities of current textbook and 5E model on the attitude of the students: Sample of "the global effects of natural resources unit". Educational Research and Reviews, 6(13), 778-785.

Ağgül-Yalçın, F., \& Avinç-Akpınar, İ. (2010). Asit-baz konusunun öğretiminde 5E öğrenme modelinin farklı öğrenme stillerine sahip ögrencilerin akademik başarılarına etkisi [The Effect of the $5 \mathrm{E}$ learning model on students with different learning styles in teaching the subject of acids and bases]. EÜFBED - Fen Bilimleri Enstitüsü Dergisi, 3(1), $1-17$.

Arends, I. R. (2001). Learning to Teach, $5^{\text {th }}$ Ed., McGraw Hill, New York.

Balc1, S. (2005). 8. sinı öğrencilerinin fotosentez ve bitkilerde solunum kavramlarını ögreniminin $5 E$ öğrenme modeli ve kavramsal değişim metinleri kullanularak geliştirilmesi. [Enriching the Learning of Photosynthesis and Plant Respiration Concepts in 8th Grade through the Use of the 5E Learning Model and Conceptual Change Texts], [Unpublished Master's Thesis], ODTÜ, Educational Sciences Institute, Ankara.

Bilgin, İ., Çoşkun, H., \& Aktaş, İ. (2012). 5E modelinin uygulandığı ilköğretim 4. sınıf öğrencilerinin eleştirel düşünme yeteneklerinin maddeyi tanıyalım ünitesindeki başarılarına etkisinin incelenmesi [Examining the effect of the 5E model on developing critical thinking in 4th graders studying the unit on matter]. X. Ulusal Fen Bilimleri ve Matematik Eğitimi Kongresi, 27-30 Haziran, Niğde. 
Boddy, N., Watson, K., \& Aubusson, P. (2003). A trial of the five Es: a referent model for constructivist teaching and learning. Research in Science Education, Netherlands: Kluwer Academic Publishers, 27-42. http://dx.doi.org/10.1023/A:1023606425452

Brooks, J. G., \& Brooks, M. G. (1993). In search of understanding: the case for constructivist classrooms. Alexandria, VA: Association for Supervision and Curriculum Development.

Brown, J. S., Collins, A., \& Duguid, P. (1989). Situated cognition and the culture of learning. Educational Researcher, 18, 32-42. http://dx.doi.org/10.3102/0013189X018001032

Bybee, R. W. (1997). Achieving scientific literacy. N. H.: Heinemann, Portsmouth.

Camnalbur, M., \& Erdoğan, Y. (2008). Bilgisayar destekli öğretimin etkililiği üzerine bir meta analiz çalışması: Türkiye örneği [A meta-analysis of the effects of computer-supported teaching: An example from Turkey]. Kuram ve Uygulamada Eğitim Bilimleri, 8, 497-505. http://dx.doi.org/10.12738/estp.2013.3.1692

Çepni, S., Küçük, M., \& Bacanak A. (2004). Bütünleştirici öğrenme yaklaşımına uygun bir öğretmen rehber materyali geliştirme çalışmast: hareket ve kuvvet. [Developing Teachers Guides for an Integrative Learning Approach]. XII. Eğitim Bilimleri Kongresi, Marmara Üniversitesi, İstanbul.

Cohen, J. (1992). Statistical power analysis. Current Directions in Psychological Science, 1(3), 98-101. http://dx.doi.org/10.1111/1467-8721.ep10768783

Cunningham, D. J. (1991). In defense of extremism. Educational Technology, 31(9), 26-27.

Deryakulu, D. (2001). Yapıcı Öğrenme. Eğitim Sen Yayınları, Ankara.

Dikici, A., Türker, H. H., \& Özdemir, G. (2010). 5E öğrenme döngüsünün anlamlı öğrenmeye etkisinin incelenmesi [Examining the effect of the 5E learning cycle on meaningful learning]. Çukurova Üniversitesi Eğitim Fakültesi Dergisi, 3(39), 100-128.

Duffy, T. M., \& Jonassen, D. H. (1991). Constructivism: New implications for instructional technology. Educational Technology, 31(5), 7-12.

Ekici, F. (2007). Yapılandırmacı yaklaşıma uygun 5E öğrenme döngüsüne göre hazırlanan ders materyalinin lise 3. sınıf ögrencilerini yükseltgenme-indirgenme tepkimeleri ve elektrokimya konuların anlamalartna etkisi [Effect of the $5 E$ Learning Cycle based on a Constructivist Approach on High School 3rd year Students' Understanding the Classroom Material on Oxidation and Reduction Reactions and Electrochemical Topics]. Unpublished Master's Thesis, Gazi Üniversitesi Eğitim Bilimleri Enstitüsü, Ankara.

Ergin, İ. (2006). Fizik eğitiminde 5E modelinin öğrencilerin akademik başarısına, tutumuna ve hatırlama düzeyine etkisine bir örnek [An example of the effect of the 5E model on students' academic achievement, attitudes and retention levels in physics education]: "iki boyutta atış hareketi. [Two-dimensional projectile motion], [PhD thesis], Gazi University, Institute of Education Sciences, Ankara.

Evans, C. (2004). Learning with inquiring minds, students are introduced to the unit on gas laws and properties of gases using the 5E model. The Science Teacher, 71(1), 27-30.

Glass, G. V. (1976). Primary secondary and meta-analysis of research. Educational Researcher, 5(10), 3-8. http://dx.doi.org/10.3102/0013189X005010003

Hiçcan, B. (2008). The influence of teaching activities with respect to $5 E$ learning cycle model on academic achievements in mathematics lesson of $7^{\text {th }}$ grade students in primary school about linear equations in one variable. Unpublished mastery thesis, Educational Sciences Institute, Ankara.

Higgins, J. P. T., Thompson, S. G., Deeks, J. J., \& Altman, D. G. (2008). Measuring inconsistency in meta-analyses. BMJ, 327, 557-560. http://dx.doi.org/10.1136/bmj.327.7414.557

Hunter, J. E., \& Schmidt, F. L. (1990). Methods of meta-analysis: correcting error and bias in research findings. London: Sage Publications. http://dx.doi.org/10.1177/1094428106295494

Kanlı, U., \& Yağbasan, R. (2008). 7E modeli merkezli laboratuvar yaklaşımının öğrencilerin bilimsel süreç becerilerini geliştirmedeki yeterliliği [The adequacy of the 7E model-based laboratory approach on students' developing scientific process skills]. GÜ, Gazi Eğitim Fakültesi Dergisi, 28(1), 91-125.

Kılavuz, Y. (2005). Yapılandırmacı Yaklaşım Teorisine Dayalı 5 E Öğrenme Döngüsü Modelinin 10. Sinıf Öğrencilerinin Asit ve Bazlarla Ilgili Kavramlarl Anlamalarina Etkisi [Effect of the Constructivist Approach-based 5E Leaning Cycle on 10th Grade Students' Understanding the Concepts of Acids and Bases]. Unpublished Master's Thesis, ODTÜ Fen Bilimleri Enstitüsü, Ankara. 
Köseoğlu, F., \& Tümay, H. (2010). Temel kimya laboratuvarlarında öğrenme döngüsü yönteminin öğrencilerin kavramsal değisim, tutum ve algılarına etkisi [The effect of the learning cycle method on student's conceptual change, attitudes and perceptions in the bsic chemistry laboratory]. Ahi Evran Üniversitesi Eğitim Fakültesi Dergisi, 11(1), 279-295.

Lawson, A. E., Abraham, M. R., \& Renner, J. W. (1989). A theory of instruction: using the learning cycle to teach science concepts and thinking skill. National Association of Research in Science Teaching, 1.

Liu, T. C., Peng, H., Wu, W. H., \& Lin, M. S. (2009). The effects of mobile natural-science learning based on the 5E learning cycle: A case study. Educational Technology \& Society, 12(4), 344-358.

Martin, D. J. (2000). Elementary science methods: a constructivist approach. Belmont, CA: Wadsworth/Thomason Learning.

Miles, M. B., \& Huberman, A. M. (1994). Qualitative data analysis: An expanded source book. Thousand Oaks, California: Sage.

Moseley, C., \& Reinke, K. (2002). Cartoon and bumber sticker science. Science Scope, 25(6), 32-34.

Newby, D. E. (2004). Using Inquiry to connect young learners to science, national charter schools institute, (http://www. nationalcharterschools. org / uploads/pdf / resource_ 20040617125804_Using\%20Inquiry.pdf).

Odom, A. L., \& Kelly, P. V. (2001). Integrating concept mapping and the learning cycle to diffusion and osmosis concepts to high school biology students. Science Teacher Education, 85(6), 615-635. http://dx.doi.org/10.1002/sce.1029

Özsevgeç, T. (2006). Kuvvet ve hareket ünitesine yönelik 5E modeline göre geliştirilen öğrenci rehber materyalinin etkililiğinin değerlendirilmesi [Evaluation of the Effectiveness of Student Guidance Materials Prepared on the Unit on Force and Motion according to the 5E Model]. Türk Fen Eğitimi Dergisi, 2(12), 36-48.

Pabuçcu, A. (2008). Improving $11^{\text {th }}$ grade students' understanding of acid-base concepts by using 5E learning cycle model. Unpublished PhD thesis, Middle East Technical University, Ankara.

Qarareh, A. O. (2012). The Effect of using the learning cycle method in teaching science on the educational achievement of the sixth graders. Int J Edu Sci, 4(2), 123-132.

Sağlam, M. (2006). Işılk ve ses ünitesine yönelik 5E etkinliklerinin gelişstirilmesi ve etkililiğinin değerlendirilmesi [Evaluation of Developing 5E Activities and their Effectiveness in the Unit on Light and Soud[. Unpublished PhD thesis, KTÜ Fen Bilimleri Enstitüsü, Trabzon.

Sakallı, A. F. (2011). Karmaşık sayılar konusunun öğretiminde yapılandırmacı 5 E modelinin öğrencilerin akademik başarllarına ve tutumlarina etkisi. [The influence of constructive 5E model on students' academic achievement and attitudes in teaching the subject of complex numbers]. Unpublished $\mathrm{PhD}$ thesis, Kahramanmaraş Sütçü İmam Üniversitesi, Fen Bilimleri Enstitüsü. Kahramanmaraş.

Saunders, W., \& Stringham, J. (1998). Learning cycle labs. Science Scope, 22(3), 38.

Tiryaki, S. (2009). Yapılandırmacı Yaklaşıma Dayalı 5E Öğrenme Modeli ve İş birlikli Öğrenme Yönteminin 8. Stnıf "Ses" Ünitesinin İşlenmesinde Başartya ve Tutuma Etkisinin Araştırllması [Exploring the Effect of the Constructivist Approach-based 5E Learning Model and the Cooperative Learning Method on the Achievements and Attitudes of 8th graders studying the unit on "Sound". Unpublished mastery thesis, Atatürk Üniversitesi Fen Bilimleri Enstitüsü, Erzurum.

Trowbridge, L. W., Bybee, R. W., \& Powell, J. C. (2000). Models for effective science teaching, teaching secondary school science strategies for developing scientific literacy, An Imprint of Prentice Hall, Upper Saddle River, New Jersey.

Wilder, M., \& Shuttleworth, P. (2004). Cell inquiry cycle lesson. Science Activities, 41(5), 25-31.

Windschitl, M. (2000). The challenges of sustaining a constructivist classroom culture. Educational Psychology, 8, 121-126.

\section{$(\mathrm{Cc}) \mathbf{B Y}$}

This work is licensed under a Creative Commons Attribution 3.0 License. 